\title{
Fortifikasi Tepung Kelapa Pada Biskuit Anak Balita
}

\author{
Coconut Flour Fortification of Toddlers Biscuits
}

\author{
Hatmiyarni Tri Handayani ${ }^{1)}$, Choirul Anam ${ }^{2)}$ \\ Program Studi Pengelolaan Perkebunan Kopi, Jurusan Produksi Pertanian, \\ Politeknik Negeri Jember ${ }^{1)}$, Program Studi Ilmu dan Teknologi Pangan, Jurusan Teknologi Pertanian, Fakultas \\ Pertanian UNS ${ }^{2)}$ \\ 1)hatmiyarni@polije.ac.id \\ 2)dikchoirul@gmail.com
}

\begin{abstract}
ABSTRAK
Tepung kelapa merupakan alternatif fortifikasi produk pangan dengan tepung terigu atau substitusi tepung terigu karena kandungan gizinya yang tinggi sehingga sangat penting untuk pengembangan produk pangan khususnya biskuit balita. Penelitian ini bertujuan untuk mengetahui proporsi tepung terigu, tepung kelapa, dan bahan baku biskuit balita yang tepat yang dapat diperoleh dari kandungan gizi, tekstur, dan panelis. Penelitian ini menggunakan proporsi tepung terigu : tepung kelapa yaitu sampel A (90\%:10\%), sampel B (80\%:20\%), dan sampel C (70\%:30\%). Hasil penelitian menunjukkan sampel yang sesuai dengan standar gizi dan kekerasan adalah sampel C (70\%:30\%) dengan kandungan protein, lemak, karbohidrat, serat, dan kekerasan masing-masing 8,75\%, $27,98 \%, 62,60 \%, 0,67 \%$, dan 177,9826N/mm2. Biskuit dengan fortifikasi tepung kelapa memiliki nilai gizi sesuai standar dan berdasarkan penilaian tingkat kelezatan dapat diterima oleh panelis.
\end{abstract}

Kata kunci : Tepung kelapa, biskuit balita

\begin{abstract}
Coconut flour is an alternative fortification of food products with wheat flour or substitution of wheat flour because high nutritions so very important to development of food products, especially toddlers biscuits. The aim of this research is to determine the right proportion of wheat flour, coconut flour, and as raw materials for toddlers biscuits that can be received from the nutrient content, texture, and panelist. This research used proportion of wheat flour : coconut flour, namely samples A (90\%:10\%), samples B (80\%:20\%), and samples C (70\%:30\%). The results showed samples that are in according with the standards of nutrition and hardnerss are samples $C$ (70\%:30\%) with protein, fat, carbohydrate, fiber contents, and hardness were 8,75\%, 27,98\%, 62,60\%, 0,67\%, and $177.9826 \mathrm{~N} / \mathrm{mm} 2$. Biscuits with coconut flour fortification had nutritional value according to standards and based on level of pleasure assessment can be accepted by panelists.
\end{abstract}

Keywords : Coconut flour, toddlers biscuits 


\section{Introduction}

\subsection{Latar Belakang}

Kandungan nutrisi dalam makanan merupakan hal yang sangat utama untuk diperhatikan dalam pemenuhan tumbuh kembang anak, sehingga anak dapat mencapai kesehatan yang optimal. Kandungan nutrisi pada anak balita harus benar-benar diperhatikan dan dilaksanakan dengan tepat agar tidak terjadi masalah gizi pada anak balita (Auliana, 2011).

Tradisi pemberian asupan makanan untuk anak balita dalam mengkonsumsi makanan berkarbohidrat tinggi dan rendah serat memicu terjadinya ketidakseimbangan dalam tubuh, seperti susah buang air besar, obesitas, dan lainlain (Kumolontang, 2014). Sumber makanan karbohidrat (contohnya serealia), protein (contohnya telur), lemak (contohnya susu), vitamin dan mineral (contohnya sayuran dan buah-buahan) sangat dibutuhkan anak balita sebagai bahan makanan tambahan.

Salah satu yang berpeluang untuk digunakan dalam komponen makanan tambahan anak balita yang nantinya bisa digolongkan ke dalam pangan fungsional adalah tepung kelapa.

Tepung kelapa dihasilkan dari kelapa kering yang diolah terlebih dahulu sebelum digunakan sebagai bahan baku produk makanan. Daging buah kelapa dikeringkan, kemudian dihaluskan dan diproses menjadi bahan pangan dalam kondisi yang aman dan higienis. Kandungan gizi pada tepung kelapa mempunyai manfaat untuk kesehatan karena mengandung minyak dan serta yang tinggi. Faktor yang mempengaruhi dalam proses pembuatan tepung kelapa adalah pada proses pengeringannya, sebab daging buah kelapa mempunyai kadar air yang tinggi sebelum dilakukan pengeringan, yaitu di atas $50 \%$. Proses pengeringan tepung kelapa dapat menggunakan sinar matahari atau mengeringkan bahan di dalam oven pada suhu 50 - $60^{\circ} \mathrm{C}$ (Lay and Pasang, 2012).

Kandungan nutrisi tepung kelapa antara lain protein $23 \%$, air $16 \%$, lemak $15 \%$, kalori 368 kal, karbohidrat 40\%, dan mineral (seperti Ca sebesar 137 mg/100 g) (Su'I, 2012). Sedangkan jika telah menjadi produk olahan, yaitu tepung, maka kandungannya antara lain protein $18,2 \%$, serat kasar 20\%, lemak 12\%, kadar air 6,2\%, dan abu 4,9\% (Yulvianti, et al., 2015).

Setiap seratus gram, ampas kelapa mempunyai kandungan nutrisi yang baik, diantaranya 56,5\% karbohidrat, 7,3\% air, 24,1\% serat kasar, 2,2\% abu, 3,5\% protein, dan 515 Kkal. Pemanfaatan ampas kelapa dalam pembuatan produk pangan masih sangat minim karena ampas kelapa cepat mengalami kerusakan, yaitu cepat mengalami ketengikan apabila tidak cepat diproses atau diolah. Salah satu cara untuk memperpanjang umur simpan ampas kelapa adalah dengan mengolahnya menjadi tepung atau dengan cara penepungan. Dengan diolah menjadi tepung, maka akan membuat kadar air menjadi berkurang dan tepung kelapa dapat menjadi bahan baku alternative dalam pembuatan produk pangan (Sabilla and Murtini, 2020).

Pemenuhan serat pangan sehari-hari pada manusia dapat dipenuhi dengan pemanfaatan ampas kelapa menjadi tepung kelapa. Kandungan yang ada di dalamnya, yaitu galaktomanan mempunyai berbagai manfaat, diantaranya memperlancar pencernaan dan sebagai sumber dietary fiber serta bermanfaat untuk kesehatan (Rosida, Susilowati, 2014). Tepung kelapa mengandung serat kasar yang tinggi sehingga dimungkinkan untuk pemanfaatan sebagai bahan baku pengolahan produk pangan, terutama pada konsumen yang rentan obesitas, diabetes, dan kardiovaskuler (Fauzan and Rustanti, 2013).

Pengolahan produk berbasis tepung kelapa sudah banyak dilakukan, antara lain dalam pembuatan kue kering dengan perbandingan tepung kelapa : tepung terigu sebagai beriku : $0 \%$ tepung kelapa : $100 \%$ tepung terigu, $25 \%$ tepung kelapa : $75 \%$ tepung terigu, $50 \%$ tepung kelapa : $50 \%$ tepung terigu, $75 \%$ tepung kelapa : $25 \%$ tepung terigu, dan 100\% tepung kelapa : 0\% tepung terigu (Polli, 2017). Sedangkan (Rosida, Susilowati, 2014) telah melakukan penelitian tepung kelapa pada pembuatan cookies dengan perbandingan sebagai berikut : 150 gram tepung terigu : 50 gram tepung kelapa, 100 gram tepung terigu : 100 gram tepung kelapa, dan 50 gram tepung terigu : 150 gram tepung kelapa.

Berdasarkan pernyataan di atas, perlu dilakukan penelitian tentang diversifikasi tepung kelapa terkait penentuan formulasi biskuit 
(tepung kelapa, tepung terigu, dan susu kambing ettawa) anak balita yang tepat yang dapat diterima dari sudut pandang kandungan nutrisi, sifat tekstur, dan penerimaan panelis.

\section{Method}

\subsection{Alat dan Bahan}

Alat pada penelitian ini adalah cabinet dryer, kempa hidraulik, blender, ayakan, oven listrik, penggilas adonan, Loyang, alat untuk analisa kimia dan tekstur. Bahan yang dipakai pada penelitian ini adalah daging kelapa yang agak tua, tepung terigu, margarin, gula halus, susu kambing ettawa, telur, baking soda untuk membuat biscuit, dan bahan untuk analisa kimia.

Perlakuan yang diuji adalah dalam penelitian ini dapat dilihat pada tabel 1 di bawah ini.

Table 1. Perlakuan Penelitian

\begin{tabular}{lll}
\hline Sampel & $\begin{array}{l}\text { Tepung } \\
\text { Terigu (\%) }\end{array}$ & $\begin{array}{l}\text { Tepung } \\
\text { Kelapa (\%) }\end{array}$ \\
\hline A & 90 & 10 \\
B & 80 & 20 \\
C & 70 & 30 \\
\hline
\end{tabular}

\subsection{Preparasi Tepung Kelapa}

Daging buah kelapa dilakukan pemisahan dengan kulit arinya, kemudian dibersihkan dan dilakukan pemarutan yang nantinya dihasilkan parutan daging kelapa. Proses pengeringan yang dilakukan menggunakan cabinet dryer pada suhu $55-60^{\circ} \mathrm{C}$ selama 15 jam. Kelapa parut kering kemudian dipress dengan press hidraulik untuk memisahkan minyak kelapa. Tepung kelapa kasar kemudian dikeringkan dan dilakukan pengecilan ukuran dengan pengayakan 20 dan 30 mesh yang akhirya dihasilkan tepung kelapa halus.

\subsection{Pengolahan Biskuit}

Pengolahan biskuit berbahan tepung kelapa sebagai berikut : 27 gr margarin, 25 gr gula halus, 1,5 gr baking soda, dan 1 butir telur dikocok hingga homogen kemudian ditambah 10 cc susu kambing ettawa untuk tiap variabel, lalu dibentuk sesuai keinginan dan dipanggang pada oven dengan suhu $110-115^{\circ} \mathrm{C}$ dalam waktu $15-20$ menit hingga matang. Proporsi tepung kelapa pada penelitian ini diupayakan tidak terlalu besar (kurang dari setengah), yaitu proporsi tepung kelapa dibatasi maksimal $40 \%$ dari bahan baku.

\subsection{Analisa}

Biskuit kelapa yang dihasilkan kemudian dianalisa kandungan nutrisinya, meliputi kandungan protrein, lemak, serat kasar, tekstur, dan uji sensoris yang menggunakan 25 orang panelis dengan usia $4-5$ tahun.

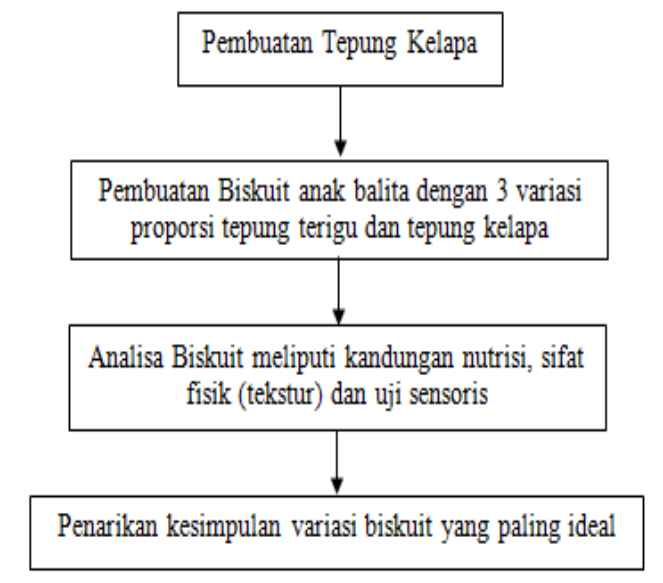

Figure 1. Diagram Alir Jalannya Penelitian Secara Keseluruhan

\section{Discussion}

\subsection{Komposisi Nutrisi Biskuit}

Berdasarkan hasil analisis data penelitian, didapatkan kandungan gizi biskuit dari penambahan tepung kelapa yang semakin banyak, akan meningkatkan kadar protein, dan kadar lemaknya namun menurunkan kadar karbohidratnya. Sedangkan untuk kadar serat kasar mengalami penurunan dan peningkatan.

Table 2. Komposisi Nutrisi Biskuit dengan Bahan Baku Tepung Terigu Dan Tepung Kelapa

\begin{tabular}{llll}
\hline $\begin{array}{l}\text { Komp } \\
\text { onen }\end{array}$ & $\begin{array}{l}\text { Komposisi } \\
(\%) \\
\text { Biskuit A }\end{array}$ & $\begin{array}{l}\text { Komposisi } \\
(\%) \\
\text { Biskuit B }\end{array}$ & $\begin{array}{l}\text { Komposis } \\
\text { i (\%) } \\
\text { Biskuit C }\end{array}$ \\
\hline Protein & 8.17 & 8.75 & 8.75 \\
Lemak & 20.89 & 25.00 & 27.98 \\
Serat & 0.65 & 0.60 & 0.67 \\
Kasar & & &
\end{tabular}


$\begin{array}{llll}\text { Karboh } & 70.29 & 65.65 & 62.60\end{array}$

idrat

Pada tabel 2 terlihat bahwa fortifikasi tepung kelapa mempunyai kandungan gizi yang sangat diperlukan oleh tubuh, sehingga tepung kelapa dapat menjadi salah satu alternatif yang tepat sebagai bahan baku dalam pembuatan biskuit anak balita.

\subsection{Protein}

Protein adalah zat gizi yang sangat penting yang berfungsi sebagai zat pembangun dan zat pengatur dalam tubuh, yang didapatkan pada makanan yang dikonsumsi yang nantinya akan diserap oleh usus dalam bentuk asam amino. Kadar protein biskuit dengan penambahan tepung kelapa berkisar antara 8,17\% - 8,75\% (Tabel 2). Hasil penelitian dapat dilihat pada gambar 2 bahwa terjadi kenaikan kadar protein dengan bertambahnya proporsi tepung kelapa. Hanya saja, kadar protein pada sampel B dan C memiliki kadar protein yang sama yaitu sebesar $8,75 \%$ yang lebih tinggi dibandingkan pada sampel A. Hal ini diakibatkan pada sampel B dan $\mathrm{C}$ proporsi tepung kelapanya semakin tinggi. Tepung kelapa tidak mengandung gluten sehingga sangat berpengaruh pada kandungan protein pada sampel. Sumber protein biskuit anak balita ini berasal dari tepung terigu, tepung kelapa, dan telur yang ditambahkan dengan proporsi yang berbeda-beda. Semakin banyak jumlah tepung kelapa yang ditambahkan pada produk, maka semakin tinggi pula kadar protein yang dihasilkan. Dengan meningkatnya kadar protein, berarti nilai tambah produk terhadap kandungan gizi biskuit anak balita semakin tinggi, karena suatu produk dikatakan bermutu baik tercermin dari kadar proteinnya. Pada penelitian ini, sampel B dan C memiliki kadar protein yang sama nilainya, dan dapat diterima oleh panelis. Hasil dari penelitian ini sejalan dengan hasil penelitian (Afrianti, Efendi, and Yusmarini, 2016) bahwa pada penelitiannya pada pembuatan kue bangkit dihasilkan kadar protein sebesar $13,91 \%$ yang disubstitusi dari $50 \%$ tepung kelapa.

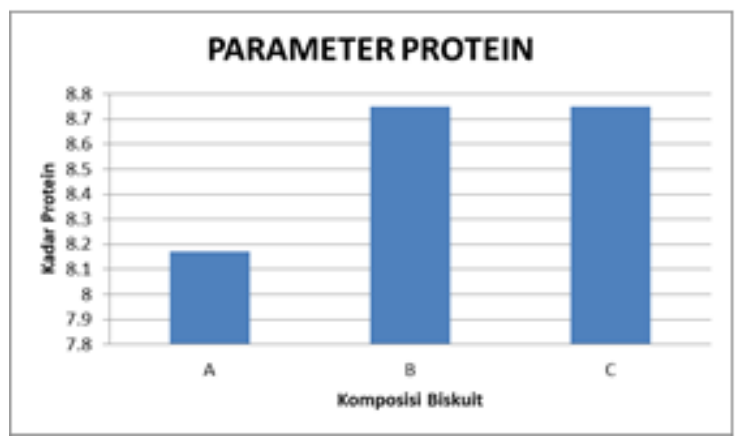

Figure 2. Parameter Protein

\subsection{Lemak}

Hasil penelitian biskuit ini menerangkan bahwa pada sampel $\mathrm{C}$ (dengan proporsi tepung kelapa sebesar 30\%) memiliki kadar lemak yang paling tinggi dibandingkan sampel B dan A, yaitu sebesar $27,98 \%$. Semakin banyak jumlah tepung kelapa yang ditambahkan, maka semakin tinggi pula kadar lemaknya. Sumber lemak pada biskuit anak balita adalah dari bahan baku dan bahan tambahannya, yaitu tepung kelapa. Hasil penelitian ini sejalan dengan yang penelitian yang telah dilakukan (Polli, 2017), bahwa kadar lemak pada kue kering sebesar 31,91\% pada formula $100 \%$ tepung kelapa. Selain itu, (Widarta, et al., 2013) juga menyatakan hasil penelitiannya pada pembuatan biskuit, bahwa penggunaan tepung kelapa sebesar $20 \%$ dari total berat basis tepung mempunyai kadar lemak sebesar $28,72 \%$.

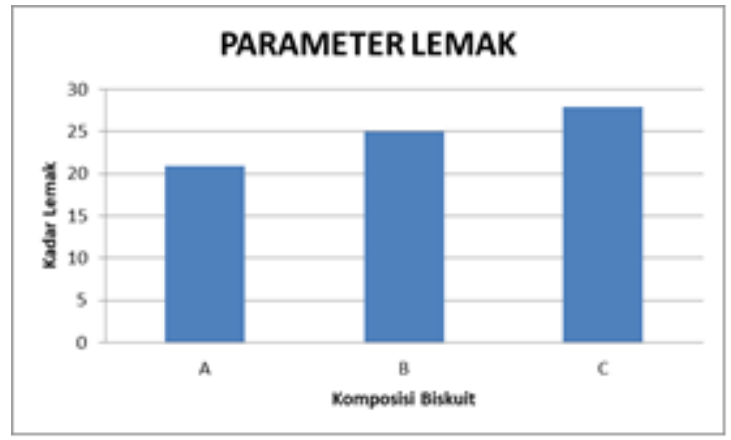

Figure 3. Parameter Lemak

\subsection{Serat Kasar}

Serat kasar berperan penting dalam mengikat air dengan sifat yang dimiliki yaitu selulosa dan pektin, dimana dapat menyebabkan feces menjadi berat, bulky (meruah), dan lunak yang dapat memungkinkan bergerak lebih cepat dan teratur melalui saluran pencernaan. Menurut (Widarta, et al., 2013), serat adalah zat gizi yang 
tidak dapat tercerna dan terserap oleh saluran pencernaan manusia, akan tetapi berfungsi penting untuk kesehatan, mencegah timbulnya penyakit, dan berperan penting dalan terapi gizi. Konsumi serat penduduk Indonesia rata-rata sebesar 30 gram setiap hairnya, dan baru memenuhi sepertiga dari kebutuhan ideal. Menurut (Polli, 2017), kandungan sesulosa pada tepung kelapa yang sangat tinggi berfungsi pada proses fisiologis tubuh. tepung kelapa mengandung selulosa cukup tinggi yang berperan dalam proses fisiologi tubuh. Selulosa adalah serat yang tidak dapat diserap oleh enzim pencernaan, tetapi berperan sangat penting dalam mempercepat waktu transit sisa makanan, sehingga dapat mengurangi timbulnya penyakit kanker usus.

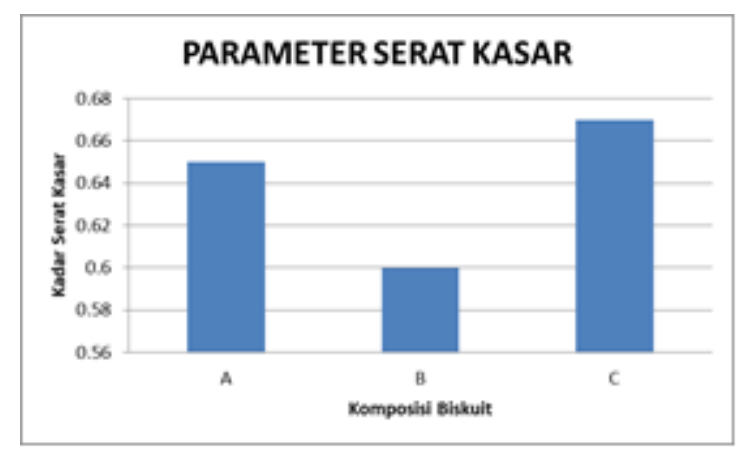

Figure 4. Parameter Serat Kasar

Beberapa penelitian yang telah dilakukan terhadap penambahan tepung kelapa pada berbagai produk pangan dihasilkan bahwa dengan adanya penambahan tepung kelapa akan membuat kadar serat kasarnya akan semakin meningkat. Hal tersebut tidak sesuai dengan hasil penelitian yang dilakukan pada produk biskuit anak balita. Pada penelitian ini mengalami penyimpangan pada sampel B. yang seharusnya mengalami peningkatan seiring dengan semakin banyaknya proporsi tambahan tepung kelapanya. Hal ini diakibatkan dalam proses pengayakan ada tepung kelapa yang tidak sepenuhnya lolos ayakan sehingga membuat kadar serat kasar tepung kelapa menjadi berkurang. Dari ketiga sampel tersebut, sampel $\mathrm{C}$ dengan penambahan tepung kelapa sebesar $30 \%$ merupakan sampel yang paling baik untuk dikonsumsi karena mengandung serat kasar yang tinggi yang bermanfaat untuk kesehatan.

\subsection{Karbohidrat}

Karbohidrat adalah sumber kalori yang berguna bagi tubuh manusia, terutama bagi Negara yang sedang berkembang. Jumlah kalori karbohidrat lebih sedikit daripada protein dan lemak, yaitu sekitar $4 \mathrm{Kal}$ (Kkal). Golongan karbohidrat yang lain menghasilkan serat-erat (dietary fiber) yang bermanfaat bagi pencernaan manusia (Hasan, 2018).

Pada gambar 5 di bawah ini terlihat bawah sampel $\mathrm{C}$ dengan proporsi tepung kelapa $30 \%$ memiliki kadar karbohidrat yang paling rendah sebesar 62,60\%, dan kadar karbohidrat yang paling tinggi terdapat pada sampel A (proporsi tepung kelapa 10\%). Hal ini dikarenakan bahwa kadar karbohidrat tepung kelapa lebih rendah dari kadar karbohidrat tepung terigu, yang berkisar 77,3\%. Hal ini sejalan dengan penelitian yang telah dilakukan (Polli, 2017) bahwa kue kering dengan penambahan tepung kelapa $100 \%$ memiliki kadar karbohidrat sebesar 45,14\% lebih rendah dibandingkan dengan kadar karbohidrat tanpa penamabahan tepung kelapa sekitar $55,41 \%$. Karbohidrat yang terdapat dalam biscuit anak balita ini adalah perpaduan antara karbohidrat dari tepung terigu dan tepung kelapa. Karbohidrat tersebut dibutuhkan sebagai sumber energi atau tenaga oleh manusia.

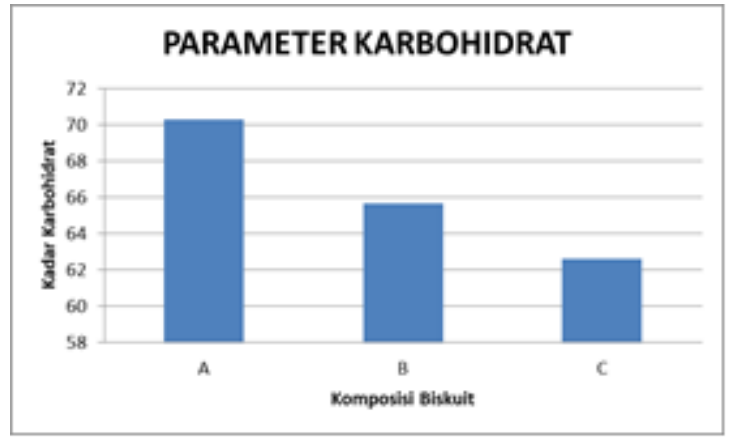

Figure 5. Parameter Karbohidrat

\subsection{Karakteristik Tekstur dan Sifat Sensoris Biskuit}

Penggunaan tepung kelapa sebagai penambahan pada produk biskuit tidak hanya akan menimbulkan perubahan pada tekstur biskuitnya, akan tetapi juga akan meimbulkan perubahan pada citarasa biskuit yang dhasilkan, karena sifat alamiah sensoris (flavor) tepung kelapa berbeda dengan tepung terigu. Nilai kekerasan biskuit dapat dilihat pada Tabel 3. 
Table 3. Nilai Kekerasan Biskuit

\begin{tabular}{lll}
\hline Biskuit & $\begin{array}{l}\text { Tepung } \\
\text { Terigu : } \\
\text { Tepung } \\
\text { Kelapa }\end{array}$ & $\begin{array}{l}\text { Tingkat } \\
\text { Kekerasan } \\
\text { (F max), } \\
\text { N/mm }\end{array}$ \\
\hline A & $90 \%: 10 \%$ & 98.7540 \\
B & $80 \%: 20 \%$ & 65.3426 \\
C & $70 \%: 30 \%$ & 177.9826 \\
\hline
\end{tabular}

Lemak adalah bahan pengempuk yang berperan penting dalam pembentukan tekstur, dimana semakin banyak kadar lemak yang dihasilkan, maka akan menyebabkan biskuit yang dihasilkan menjadi tidak keras. Hal ini ditunjukkan oleh respon bahan ketika diberi beban pada Lyod, nilainya semakin kecil, sehingga dapat diartikan bahwa produk biskuit tersebut semakin tidak keras.

Prosentase kelunakan pada biskuit dipengaruhi oleh kandungan galaktomanan yang terdapat pada dalam daging buah kelapa. Galaktomanan adalah bagian dari polisakarida yang diperoleh dari tanaman kacang-kacangan (Leguminaceae) yang tumbuh di daerah semi kering. Pada daging buah kelapa terkandung juga galaktomanan, dimana galaktomanan akan semakin meningkat dengan semakin matang buah kelapa tersebut. Hal ini terbukti bahwa pada ampas kelapa kadar galaktomanannya sangat tinggi (Barlina, 2015).

Pada tabel 3. Terlihat bahwa tingkat kekerasan C (proporsi 30\% tepung kelapa) bernilai paling besar dibandingkan biskuit yang lain sebesar $177.9826 \mathrm{~N} / \mathrm{mm}^{2}$, dan yang paling rendah nilai kekerasannya terdapat pada sampel B (proporsi tepung kelapa 20\%) sebesar 65.3426 $\mathrm{N} / \mathrm{mm}^{2}$. Pada sampel B ini terjadi penyimpangan yang mungkin diakibatkan pada saat pencampuran adonan yang kurang maksimal, sehingga mengakibatkan lemak tidak dapat terdistribusi secara merata ke seluruh adonan. Kita ketahui bahwa lemak merupakan komponen yang sangat penting dan berpengaruh dalam tekstur biskuit. Hasil dari penelitian ini sejalan dengan pernyataan (Lubis, 2014) bahwa pada pembuatan kue kering dengan penambahan $75 \%$ tepung kelapa menghasilkan nilai organoleptik tertinggi dibandingkan sampel lainnya. Tekstur dari biskuit adalah perpaduan dari tingkat kerenyahan, tidak terlalu keras, dan tidak mudah hancur. Salah satu faktor yang berperan dalam pembentukan tekstur pada biskuit adalah dengan adanya telur, karena telur tidak akan berikatan dengan serat tepung kelapa apabila berada di dalam adonan sehingga akan membentuk komposit yang kompak.

Penambahan tepung kelapa sebagai bahan baku biskuit tidak mengakibatkan penurunan kualitas sifat fisik biscuit. Berdasarkan uji kesukaan yang telah dilakukan pada panelis anak balita usia 4-5 tahun, didapatkan bahwa seluruh sampel biskuit dapat diterima oleh panelis, akan tetapi untuk sampel $\mathrm{C}$ yang paling disukai. Semakin banyak jumlah penambahan tepung kelapa ke dalam produk biskuit anak balita, maka semakin disukai panelis karena tepung kelapa memiliki rasa gurih yang khas.

Perbedaan citarasa dari tepung kelapa dengan tepung terigu yang sangat signifikan adalah pada rasa manisnya, yaitu untuk tepung kelapa lebih terasa manis dibandingkan tepung terigu. Fortifikasi tepung kelapa mengakibatkan perubahan pada kandungan nutrisi, sifat tekstural dan sensoris (tingkat kesukaan) biskuit. Berdasarkan kandungan nutrisi, untuk sampel penelitian yang masih memenuhi persyaratan kandungan zat gizi adalah biskuit dengan proporsi tepung terigu : tepung kelapa $=80 \%$ : $20 \%$.

\section{Conclusion}

\subsection{Kesimpulan}

Fortifikasi tepung kelapa untuk biskuit anak balita yang memenuhi kandungan nutrisinya adalah biskuit biskuit $\mathrm{C}$ dengan proporsi bahan baku tepung terigu : tepung kelapa $=70 \%: 30 \%$. Penggunaan tepung kelapa sebagai bahan baku biskuit anak balita akan mengakibatkan peningkatan kandungan protein dan lemak, dan akan menurunkan kandungan karbohidratnya.

Untuk nilai kekerasan, biskuit yang paling baik untuk dikonsumsi anak balita adalah biscuit $\mathrm{C}$ dengan proporsi tepung terigu : tepung kelapa $=70 \%: 30 \%$, dengan nilai kekerasan 177.9826 $\mathrm{N} / \mathrm{mm} 2$. Sedangkan variasi biskuit yang paling disukai panelis adalah biskuit $\mathrm{C}$ dengan proporsi tepung terigu : tepung kelapa $=70 \%: 30 \%$. 
Dari penelitian yang dilakukan, biscuit $\mathrm{C}$ dengan proporsi tepung terigu : tepung kelapa $=$ $70 \%$ : $30 \%$ adalah biskuit yang paling dapat diterima oleh panelis baik dari segi kandungan nutrisi dan teksturnya.

\subsection{Saran}

Penelitian ini memerlukan penelitian lebih lanjut dalam sasaran pengaplikasian produk biskuit yang terbaik dari penelitian untuk anak autis, mengingat anak autis tidak diperkenankan memakan biskuit yang mengandung gluten.

\section{References}

[1] Afrianti, Fitri, Raswen Efendi, and Yusmarini. 2016. "Pemanfaatan Pati Sagu Dan Tepung Kelapa Dalam Pembuatan Kue Bangkit.” JOM Faperta UR 3(2): 116.

[2] Auliana, Rizqie. 2011. "Gizi Seimbang Dan Makanan Sehat Untuk Anak Usia Dini." Journal of Nutrition and food research 2(1): 1-12. http://staff.uny.ac.id/sites/default/files/pengabdian/ri zqie-auliana-dra-mkes/gizi-seimbang-dan-makanansehat-untuk-anak-usia-dini.pdf.

[3] Barlina, Rindengan. 2015. "Ekstrak Galaktomanan Pada Daging Buah Kelapa Dan Ampasnya Serta Manfaatnya Untuk Pangan." Perspektif 14(Vol 14, No 1 (2015): Juni, 2015): 37-49. http://ejurnal.litbang.pertanian.go.id/index.php/psp/a rticle/view/3399.

[4] Fauzan, Muthia, and Ninik Rustanti. 2013. "Pengaruh Substitusi Tepung Ampas Kelapa Terhadap Kandungan Zat Gizi, Serat Dan Volume Pengembangan Roti." Journal of Nutrition College 2(4): 630-37.

[5] Hasan, Irma. 2018. "Pengaruh Perbandingan Tepung Ampas Kelapa Dengan Tepung Terigu Terhadap Mutu Brownies." Gorontalo Agriculture Technology Journal 1(1): 59

[6] Kumolontang, Nova. 2014. "Tepung Kelapa Sebagai Substituen Parsial Dalam Pembuatan White Bread." Jurnal Penelitian Teknologi Industri 6(2): 63-70.

[7] Lay, Abner, and Patrik M. Pasang. 2012. "Strategi Dan Implementasi Pengembangan Produk Kelapa Masa Depan." Perspektif 11(1): 1-22.

[8] Lubis, Yanti Meldasari. 2014. "Formulasi Biskuit Kelapa Parut Kering Dengan Perlakuan Penyangraian Dan Tanpa Penyangraian." Jurnal Teknologi dan Industri Pertanian Indonesia 6(2).

[9] Polli, Fahri ferdinand. 2017. "Pengaruh Subtitusi Tepung Kelapa Terhadap Kandungan Gizi Dan Sifat Organoleptik Kue Kering." Buletin Palma 18(2): 9198.
[10] Rosida, Susilowati, Manggarani. 2014. "Kajian Kualitas Cookies Ampas Kelapa.” 8(10): 1415-20.

[11] Sabilla, Nurrahmah Fitra, and Erni Sofia Murtini. 2020. "Pemanfaatan Tepung Ampas Kelapa Dalam Pembuatan Flakes Cereal (Kajian Proporsi Tepung Ampas Kelapa: Tepung Beras)." Jurnal Teknologi Pertanian 21(3): 155-64.

[12] Su'I, Sukamto dan Harmanto. 2012. "Modifikasi Pengolahan Minyak Kelapa Untuk Meningkatkan Kualitas Ampas Minyak Kelapa.” Jurnal Teknologi Pertanian 5(1): 20-25.

[13] Widarta, I W.R. et al. 2013. "Pelatihan Pengolahan Tepung Ampas Kelapa Menjadi Biskuit.” 12(2): 6365.

[14] Yulvianti, Meri, Widya Ernayati, Tarsono, and Muhammad Alfian R. 2015. "Pemanfaatan Ampas Kelapa Sebagai Bahan Baku Tepung Kelapa Tinggi Serat Dengan Metode Freeze Drying." J. Integrasi Proses 5(2): 101-7. 